\title{
Mammals in the Mexican Official Norm NOM-059-SEMARNAT-2010
}

\author{
Consuelo Lorenzo ${ }^{1 *}$ and Noé GonzÁlez-Ruiz² \\ 1 Departamento Conservación de la Biodiversidad, El Colegio de la Frontera Sur. Carretera Panamericana y Periférico Sur s/n, C.P. \\ 29290, San Cristóbal de Las Casas. Chiapas, México. Email: clorenzo@ecosur.mx (CL). \\ 2 Departamento de Biología, División de Ciencias Biológicas y de la Salud, Universidad Autónoma Metropolitana, Unidad \\ Iztapalapa, Apartado Postal 55-535, C.P. 09340. Ciudad de México, México. E-mail: noegr@xanum.uam.mx (NGR). \\ *Corresponding author
}

This paper describes the procedure for applying the Method to Assess the Risk of Extinction of Wild species in Mexico (MER, for its acronym in Spanish') in order to contribute to modify the risk categories of taxa (species and subspecies) listed in the Mexican Official Norm NOM-059-SEMARNAT-2010 (NOM-059). Additionally, we analyzed the mammal taxa listed in NOM-059 as regards taxonomy and current biological knowledge status. We concluded the following: 1) the procedures to approve the collection of specimens of the species listed in NOM-059 through scientific collection licenses and in protected natural areas should be simplified; 2) the list of species in NOM-059 should be regularly updated to include any changes in the taxonomic classification of the different taxa included, with 51 accounted for to date; 3 ) updated information should be included on the conservation status of species and subspecies. In addition, it is necessary to conduct further systematic and long-term monitoring studies to obtain in-depth information on the biology, ecology, distribution and threats for endemic species and populations listed in any risk category in NOM-059; in this regard, the opinion of experts in mammal ecology, conservation and taxonomy is key. If the above is fulfilled, a larger number of taxa will be included in NOM-059 using MER, with a direct impact on the conservation policy of species listed in a risk category.

Damos a conocer los procedimientos para aplicar el Método de Evaluación del Riesgo de Extinción de las Especies Silvestres en México (MER) con el fin de incidir en los cambios de las categorías de riesgo de los taxa (especies y subespecies) listados en la Norma Oficial Mexicana, NOM-059-SEMARNAT-2010 (NOM-059). Igualmente hacemos un análisis de los taxa de mamíferos que se encuentran listados en la NOM-059, en relación con su taxonomía y estado actual de conocimiento biológico. Concluimos que: 1) es importante simplificar los trámites que permitan la colecta de ejemplares de especies contempladas en la NOM-059 en las licencias de colector científico y dentro de áreas naturales protegidas, 2) la lista de la NOM-059 debe ser actualizada continuamente por los cambios taxonómicos de los diferentes taxa que los conforman y que a la fecha contabilizamos 51,3) se incluya nueva información sobre el estado de conservación de las especies y subespecies. Además, se requiere realizar mayor número de estudios de monitoreo sistemáticos y a largo plazo y obtener datos contundentes sobre la biología, ecología, distribución y amenazas en las poblaciones y especies endémicas y en categoría de riesgo en la NOM-059, para lo cual la opinión de expertos en ecología, conservación y taxonomía de mamíferos es muy importante. Si se cumple lo anterior, mayor número de taxa contarán con el MER en la NOM-059 y podremos influir directamente en la política de conservación de especies en categoría de riesgo.

Keywords: scientific collection; conservation; endemisms; red list; mammals at risk; Mexico.

๑c 2018 Asociación Mexicana de Mastozoología, www.mastozoologiamexicana.org

${ }^{1}$ Unless otherwise stated, all the acronyms herein refer to the name in Spanish (translator's note).

The Mexican Official Norm NOM-059-SEMARNAT-2010 (NOM-059) was published in the Federal Official Gazette in November 2010. This norm lists "the species or populations at risk, based on the identification and monitoring of ecosystems and habitats that contain a large number of wildlife species that are endemic or endangered; of social, economic, cultural or scientific importance; representative or unique; or linked to evolutionary or other biological processes of paramount importance" (SEMARNAT 2010). Such information considers the population as the target for actions aimed at protection, conservation and sustainable use. Its characteristics are key for the assessment of the risk of extinction, being identified as species and populations listed under the following categories: a) endangered of extinction, b) threatened, c) subject to special protection, and d) probably extinct in the wild (SEMARNAT 2010).

Any person may promote the modification of the list through the inclusion, exclusion or change of category of any species or population (SEMARNAT 2010). Changes are made by submitting the following to SEMARNAT: 1) a scientific-technical rationale that should include (for each taxon) biological, ecological, economic, cultural and distribution data; actual and potential risk factors; actions to be taken by authorities as a result of the proposal; and a costbenefit analysis; 2 ) information used for determining the risk category in accordance with the regulatory annexes of the Method to Assess the Risk of Extinction of Wild species in Mexico (MER) or the Method to Assess the Risk of Extinction of Plants. The four MER criteria should be ranked: A) magnitude of the distribution range of the taxon in Mexico; B) status of the habitat with respect to the natural development of the taxon; $C$ ) intrinsic biological vulnerability of the taxon; D) impact of human activities on the taxon. Conventional numeric values are assigned, in ascending order of risk, which are subsequently added up.

The first part of this note provides information on the procedures for the application of the MER to mammals; the 
activities that should be taken into account; the documentation required to submit requests of changes to NOM-059; the limitations and problems associated with their application; and the actions and recommendations (as conclusions) we believe should be taken into account in order to solve them. The second part includes an analysis of the mammal taxa listed in NOM-059, as regards taxonomy and current status of biological knowledge.

\section{NOM-059 and MER}

MER uses criteria that are widely recognized for their relationship with the potential or vulnerability of extinction, and is applied as a generalized and unified method for determining the extinction-risk category that may be assigned to any wild species (or population) (Tambutti et al. 2001, Sánchez et al. 2007). Additionally, this method is intended to be used as a simple tool and considers the lack of information for several species in Mexico (Sánchez et al. 2007). It has been applied in the previous revisions of the NOM-059 (SEMARNAT 2002, 2010).

We are convinced that field work information is essential for estimating the risk of extinction of a given species, for which long-term studies are required (three to five years); the larger the amount of data, the more robust the MER will be. Some of these data can be obtained from voucher specimens deposited in biological collections and the literature, including the description of the species or subspecies and their historical distribution. Other data are obtained only through field work; the methodology used depends on the particular information and species under evaluation, including current distribution (photographic records, recent collection and georeferencing of specimens observed); population density (observation of specimens along transects, number of specimens per trap or capture effort); habitat features (sampling of plant associations and assessment of variables such as composition, cover and frequency of plant species along transects); habitat use (calculation of the proportion of use in each plant association); home range (radiolabelling or records of movements of each individual in a population); reproduction (direct observation to estimate the onset and duration of the reproductive season and reproductive potential); feeding habits (comparison of stomach contents or excreta with the main species distributed in the area); associated fauna (through literature search and direct observations of excreta and footprints in the field). The information obtained will be essential to apply the criteria B, C and D of the MER.

If the field study involves the collection of specimens, a special scientific collection license issued by SEMARNAT should be requested and obtained in advance. However, licenses for researchers and scientific collectors from research institutions (modality A) "do not support the scientific collection of species listed in the NOM". Additionally, a letter of acceptance in the National System of Researchers (SNI) should be submitted (as part of a number of documents); this further restricts the conduct of research proj- ects, since not all researchers are registered in the System. The above hampers the collection of biological data on the species (as abundance, reproduction and ecology data), and therefore, there will be gaps in their knowledge and the applicability of the MER.

If a field study involves the collection of specimens in a Natural Protected Area (ANP), it should first be approved by the National Commission of Natural Protected Areas (CONANP), which requires the submission of a schedule of activities, list of participants, date of registration to the ANP and copy of the updated scientific collecting license. In some cases, it is necessary to submit a license for the collection of parts and derivatives of the specimens under study, e.g. hairs and excreta. This further restricts the collection of biological data in the field. To note, scientific collection licenses by line of research are currently granted (if all the requirements are met) to collect only two specimens per species and locality, that have not been collected previously and the species are not listed in the NOM-059. This number of specimens is insufficient to carry out a proper biological study.

If all these requirements are met and there is sufficient information to provide data to the MER, the criteria can be ranked to assign new categories of risk of extinction to the species or subspecies under study, which must be approved by the National Advisory Committee for the Standardization of Environment and Natural Resources at SEMARNAT.

\section{Mammals and NOM-059}

The NOM-059 lists 291 taxa of mammals, 194 of which are species, accounting for $35.8 \%$ of the total number of mammals in Mexico ( 542 spp, according to MedranoGonzález et al. 2008; Ramírez-Pulido et al. 2014, and ÁlvarezCastañeda et al. 2017). The Orders with the largest number of species are Rodentia (rodents), Chiroptera (bats), Cetacea (whales, dolphins, porpoises, killer whales, sperm whales, porpoise) and Soricomorpha (shrews; Table 1). However, this list could be modified substantially if three relevant points are considered. 1) Since the publication of the latest revision of the NOM-059 (SEMARNAT 2010), 51 taxonomic modifications have taken place that affect species or subspecies listed in the NOM-059. Most of these changes confuse and have a substantial impact on the implementation of conservation plans (Morrison et al. 2009). 2) In the past seven years, some studies have challenged the conservation category of some taxa or have proposed the inclusion or exclusion of some species (e. g., Fernández et al. 2014; González-Ruiz et al. 2014; Lorenzo et al. 2016). 3) Increasingly better and more in-depth information is becoming available on the species listed in the NOM-059; this allows not only the modification of risk categories, but also the improvement of conservation plans for each species (e. g., Lorenzo et al. 2012).

Of the total number of mammal taxa in the NOM-059, only 34 species (11.7\%) have a MER; this suggests that there is insufficient information for most species in the list to 
Table 1. Number of mammal species listed in the Mexican Official Norm NOM059-SEMARNAT-2010 (NOM) by taxonomic order, including endemic species and species registered according to different authors.

\begin{tabular}{|c|c|c|c|c|c|}
\hline & Total & Endemic & Terrestrial & Terrestrial & Marine \\
\hline Order & NOM & NOM & $\begin{array}{c}\text { Ramírez- } \\
\text { Pulido et } \\
\text { al. } 2014 \\
\end{array}$ & $\begin{array}{c}\text { Álvarez- } \\
\text { Castañeda } \\
\text { et al. } 2017 \\
\end{array}$ & $\begin{array}{c}\text { Medrano- } \\
\text { González et } \\
\text { al. } 2008\end{array}$ \\
\hline Carnivora & 23 & 7 & 32 & 35 & \\
\hline Cetacea & 37 & 1 & & & $\sim 39$ \\
\hline Cingulata & 1 & 0 & 2 & 2 & \\
\hline Chiroptera & 38 & 6 & 139 & 142 & \\
\hline Didelphimorphia & 3 & 0 & 9 & 8 & \\
\hline Erinaceomorpha & 3 & 0 & & & \\
\hline Soricomorpha* & & & 3 & 3 & \\
\hline Lagomorpha & 10 & 10 & 14 & 15 & \\
\hline Perissodactyla & 1 & 0 & 1 & 1 & \\
\hline Pilosa & 3 & 1 & 2 & 2 & \\
\hline Pinnipedia & 5 & 1 & & & 6 \\
\hline Primates & 3 & 0 & 3 & 3 & \\
\hline Rodentia & 131 & 111 & 246 & 254 & \\
\hline Sirenia & 1 & 0 & & 1 & 1 \\
\hline Soricomorpha & 26 & 19 & 38 & 39 & \\
\hline Artiodactyla & 6 & 2 & 10 & 10 & \\
\hline Total & 291 & 158 & 496 & 512 & $\sim 46$ \\
\hline
\end{tabular}

* The NOM considers the Order Erinaceomorpha, while Ramírez-Pulido et al. 2014, and Álvarez-Castañeda et al. 2017 use the Order Soricomorpha.

apply the MER, and hence their permanence in the list lacks a solid and reliable support. In addition, a little over half of the mammal species (158 spp; 54.3\%) listed in the NOM059 are endemic to Mexico (Table 1); most have a restricted distribution (often outside of protected natural areas), only a few individuals have been observed, their biology and ecology are unknown, and there are monitoring flaws, so its conservation status is in doubt, with artificial categories and without methodological support (Lorenzo et al. 2016).

\section{Conclusions}

One key aspect to consider is the simplification of the administrative procedures to approve the collection of specimens of species listed in the NOM-059 in relation to scientific collection licenses and in Protected Natural Areas. Scientific collections should be fully supported based on the ultimate goal to produce and disseminate scientific and biological knowledge, and specimens should be deposited in scientific collections registered at SEMARNAT.

Since the content of the NOM-059 is amended mainly as a result of new information and taxonomic changes, and only occasionally as a result of studies on the conservation status of the species, the NOM-059 should be regularly updated - at least every three years - as set forth in NOM-059 itself. However, seven years have passed since the latest list was issued. Although there is a Draft Amendment of Regulatory Annex III (http://dof.gob.mx/normasOficiales.php?codp $=5877 \& v i e w=s i)$, this only updates the names of species, without a clear taxonomic modification involving the conceptualization of the species and not only an update of its name. But the main problem for which the NOM-059 is not modified, is the lack of in-depth studies with updated data, which cannot be conducted due to the current lack of administrative resources and limitations, even when economic resources are available. Endemic species and those listed in any risk category require a larger number of studies such as systematic and long-term surveys, to obtain conclusive data on the biology, ecology, distribution and threats of populations, which will affect technical-scientific reports and implementation of the MER with the most complete data possible. The process of renewal the NOM-059, in addition to updating it, should involve the opinion of experts and economic resources to conduct research on the species listed in the NOM-059 and/ or potentially at risk.

Even with the administrative formalities and restrictions involved, the participation of scientists should be encouraged to influence the conservation policies of the species listed in a risk category. While, according to the law, any person may propose changes to the NOM-059, academics are the stakeholders that should lead these modifications, because they are the ones who request collection licenses and have access to the right equipment, knowledge and information. The vast work needed to obtain this information requires the collaborative participation of academic experts in mammal ecology, conservation and taxonomy. It is here where the Asociación Mexicana de Mastozoología, A. C. (Mexican Association of Mammalogy, AMMAC), as a key consultant for NOM-059, should gather and organize its members to focus efforts on a list of species at risk that be inclusive, complete and data-based.

\section{Literature cited}

Álvarez-Castañeda, S. T., T. Alvarez, and N. González-Ruiz. 2017. Keys for Identifying Mexican Mammals. The Johns Hopkins University Press.

Fernández, J. A., M. S. Hafner, D. J. Hafner, and F. A. Cervantes. 2014. Estado de conservación de los roedores de las familias Geomyidae y Heteromyidae de México. Revista Mexicana de Biodiversidad 85:576-588.

González-Ruiz, N., J. Ramírez-Pulido, and M. Gual-Díaz. 2014. Mamíferos de bosque mesófilo de montaña en México. Pp. 305-326 in Bosques Mesófilos de Montaña de México: diversidad, ecología y manejo (Gual-Díaz M., and A. RendónCorrea, comp.). Comisión Nacional para el Conocimiento y Uso de la Biodiversidad. Ciudad de México, México.

Lorenzo, C., M. Briones-Salas, and S. T. Álvarez-Castañeda. 2016. The current status of micro endemic species of mammals and their prospects of conservation in southern Mexico. Therya 7:353-356.

Lorenzo, C., A. Carrillo-Reyes, T. Rioja-Paradela, and M. de La PazCuevas. 2012. Estado actual de conservación de liebres insulares en Baja California Sur, México. Therya 3:185-206.

Medrano-González, L., H. Rosales-Nanduca, M. J. Vázquez-Cuevas, J. Urbán-Ramírez, L. Rojas-Bracho, M. A. Salinas-Zacarías, L. F. Bourillón-Moreno, L. Viloria-Gómora, E. M. Peters-Recagno, and A. Aguayo-Lobo. 2008. Diversidad, composiciones comunitarias 
y estructuras poblacionales de la mastofauna marina en el pacífico mexicano y aguas circundantes. Pp. 469-492 in Avances en el Estudio de los Mamíferos de México. Publicaciones Especiales, Vol. II (Lorenzo, C., E. Espinoza, and J. Ortega, eds.). Asociación Mexicana de Mastozoología, A. C. Ciudad de México, México.

MorRIson, W.R., J. L. Lohr, P. Duchen, R. WiLChes, D. TruJILlo, M. MAIR, AND S. S. Renner. 2009. The impact of taxonomic change on conservation: Does it kill, can it save, or is it just irrelevant? Biological Conservation 142:3201-3206.

Ramírez-Pulido, J., N. Gonzalez-Ruiz, A. L. Gardner, and J. ArroyoCABRALES. 2014. List of recent land mammals of Mexico, 2014. Special Publications, Museum of Texas Tech University 63:1-69. Sánchez, O., R. Medellín, A. Aldama, B. Goettsch, J. Soberón, and M. TAMBUTti. 2007. Método de evaluación del riesgo de extinción de las especies silvestres en México (MER). Instituto Nacional de Ecología y Comisión Nacional para el Conocimiento y Uso de la Biodiversidad. Ciudad de México, México.

Semarnat (Secretaría de Medio Ambiente y Recursos Naturales). 2002. Norma Oficial Mexicana NOM-059- ECOL-2001. Protección ambiental-Especies nativas de México de flora y fauna silvestres-Categorías de riesgo y especificaciones para su inclusión, exclusión o cambio, y lista de especies en riesgo. Diario Oficial de la Federación, 6 de marzo de 2002, Segunda Sección. Ciudad de México, México.

Semarnat (Secretaría de Medio Ambiente y Recursos Naturales). 2010. Norma Oficial Mexicana NOM-059-SEMARNAT-2010. Protección ambiental, especies nativas de flora y fauna silvestres de México, categorías de riesgo y especificaciones para su inclusión, exclusión o cambio, y lista de especies en riesgo. Diario Oficial de la Federación, 30 de diciembre de 2010, Segunda Sección. Ciudad de México, México.

Tambutti, M., A. Aldama, O. Sánchez, R. Medellín, and J. Soberón. 2001. La determinación del riesgo de extinción de especies silvestres en México. Gaceta Ecológica 61:11-21.

Associated editor: Sergio Ticul Alvarez-Castañeda Submitted: November 7, 2017; Reviewed: November 15, 2017;

Accepted: November 15, 2017; Published on line: December 18, 2017. 